특별기고

\title{
The Concept of Freedom in the Political Theory of Late Medieval Scholasticism*
}

Jürgen Miethke

"Freiheit - ein schönes Wort - wer's recht verstände! (Freedom, a nice word - if there is anyone who understands its meaning correctly)". Johann Wolfgang von Goethe, one of the greatest German authors, formulated this remark in his tragedy 'Egmont', written from 1775 to 1787. Here Goethe presented to the public a 'great man' of the sixteenth century, reflecting the uprising of the Netherlands against the Spanish king for the sake of freedom and liberty. Before and after Goethe many people have written many pages on the semantics of freedom and liberty.1) But still today, when we speak of freedom, we

* Paper read in Waseda University, Tokyo, on 18th of October 2013 and at Sungkyunkwan University on 30th of October 2013.

1) An overview is given e.g. in: Christian Meier, Jochen Bleicken, Werner Conze, Gerhard May, Christof Dipper, Horst Günther, Diethelm Klippel, Geschichtliche Grundbegriffe, Historisches Lexikon zur politisch-sozialen Sprache in Deutschland, eds. Otto Brunner, Werner Conze, Reinhart Koselleck, vol. 2(Stuttgart 1975), pp. 425-542; cf. W. Warnmach, Hermann 
often don't know exactly what we mean by this concept. I cannot claim to sharpen with my considerations how we understand freedom in our present time. But I want to give some examples of thoughts on political freedom in later medieval scholasticism by taking some examples for our review. With this, we shall be able to have an impression of the prehistory of freedom as a political concept immediately at and before the beginnings of modernity. This may help us to have a better look at the complexity of the phenomenon even today.

A proper 'political science' as a scientific discipline with specific methods and a certain bundle of questions, all of which were very distinct from other disciplines, did not exist at the 'scholastic' universities in late medieval Europe. An independent discipline of its own was invented only with the beginning of modern times, i.e. in the 16th century. The name of the theorist who is normally considered to be the inventor of an independent political science is Niccolò Machiavelli (who died

Otto Pesch, Historisches Wörterbuch der Philosophie, ed. von Joachim Ritter, vol. 2(Basel 1972), pp. 1064-1098; for the middle ages shortly: Claus Schott, Hermann Otto Pesch, Lexikon des Mittelalters, vol. 4 (München/ Zürich 1989), pp. 896-901. The main literature: Herbert Grundmann, "Freiheit als religiöses, politisches und persönliches Postulat im Mittelalter", Historische Zeitschrift 183(1957) pp. 23-53; Wilhelm Berges, "Selbstbestimmung in der Geschichte", Freiheit als Problem der Wissenschaft(Freie Universität Berlin, Abendvorträge im Winter 1961/62), (Berlin 1963), pp. 147-160; Johannes Fried, "Über den Universalismus der Freiheit im Mittelalter", Historische Zeitschrift 240(1985), pp. 313-361; as well as the anthology: Die abendländische Freiheit vom 10. zum 14. Jahrhundert, Der Wirkungszusammenhang von Idee und Wirklichkeit im europäischen Vergleich, ed. von Johannes Fried(Vorträge und Forschungen, 39)(Sigmaringen 1991). 
1527). It is his name which is always on the tongue of all historians dealing with this question, and with Machiavelli we get far away from scholasticism and medieval universities to Renaissance Florence and the politics of modernity.

This is the key difference from our contemporary universities all over the world. The different scholastic faculties were distinct from each other mainly by their basic textbooks and their concomitant traditions, not by methods of thinking or procedures of research. The theologians had on their side the Holy Bible and the church fathers, the jurists, the Corpus Iuris civilis or the Corpus Iuris canonici, the physicians used Arabic and ancient Greek medical texts in Latin translations, and the members of the Arts Faculty looked more towards Aristotle and the Corpus of his writings in addition to the elder Roman texts of Cicero. But all the men who studied at one of these different faculties could be addressed with questions by rulers and practical politicians about how to answer a specific political question, how to argue for a special practical solution, how to plan to legitimize a certain deed. All of these university-trained men had a strong tendency to seek an answer that was rooted in their own respective traditions, i.e. within their own scientific discipline. Today you can still see whether a certain political treatise was written by a theologian, a lawyer or an artist (i.e. a member of a philosophical faculty) even if the answers in a practical respect were not too far away from each other.

It seems to me adequate, therefore, to call all the four main faculties of the scholastic university a sort of 'leading sciences' for 
the political theory of the later Middle Ages. It is similar to the concept of the different 'languages' of the medieval political theories, as they were called by the Cambridge school of political science, especially by Quentin Skinner and his students, giving an explanation for the unity in content and the differences in construction in political theories of the later Middle Ages. But I prefer this metaphor of 'leading science' to the broader Cambridge metaphor of 'language', because a 'theory' seems to me only in a very restricted sense comparable to a 'language'.

Today it is easy to realize which faculty had hosted the author of a special political treatise. Rather, political theories did belong to the context of the efforts of medieval scholasticism. They belonged to those efforts, which may be called the practical 'output' of scholastic science, i.e. the practical consequences of medieval scientific thought. Today we can easily see the faculty or faculties which have formed an author of political tracts. For instance, Marsilius of Padua had been a Master of Arts and a student of medicine and theology at the University of Paris, and you may detect easily these origins and qualifications in the very text of his Defensor pacis. The same applies, mutatis mutandis, with all other authors, as we can see with Thomas Aquinas or William of Ockham, who were theologians, with Bartolus of Sassoferrato, Nicolaus Tedeschi or Lupold of Bebgenburg, who were lawyers, and so on through the whole series of late medieval political theorists.

If we try to explain the difference between the faculties and their function as leading sciences of political theory on the one 
side and the unity which they show in their guidelines for practical politics, an answer may already be the simple hint at a slow and steady differentiation of the subject 'politics', which took place during a lengthy process that could not be accomplished in a period of one or two generations. But with this answer we stay only at the surface of the phenomenon, as we don't get any information about the conditions of the political thought of scholasticism, with the secret goal of a 'political theory' in the modern sense of the word.

I want to emphasize that the medieval scholars, whether at the University or after having completed their university education, wanted to respond to the problems of their contemporary world based on their experience with their texts and treatises and the thoughts they had learned during their long and complicated university education. They all wanted to use what they had learned in their studies. The medieval world, the rulers and practicians, wanted to use the scientific experts generally, wherever they could reach them, because this was a sort of legitimation by traditional and reasonable insights into social structures, which was offered to them by the treasure of the old texts. In the Middle ages, political theory tried to give answers to a perceived urgency of the contemporary situation and its requests, and that means they did not answer only or not primarily to their scientific environment. They were trying to respond to the search for scientific guidance in everyday problems. They tried in an eminent sense to give a practical application of scientific theory to everyday life in their own 
time.

This means for our own interpretation of medieval discussions that we meet here again the deep unity of the medieval understanding of the world which shaped the results also of the theoretical discussions of politics beyond all the differences in the individual and yet so significant discrepancies in the practical advice, which was given to the practicians. A coherent fundamental unity can be observed in those very different answers that were given, because of the common methodological approach of scholasticism. So far it is allowed, perhaps even necessary, to question not only one author on his comments, but to screen the different positions in comparison with each other, in order to seek for such common ground. In the following paper I want to look for the concept of freedom in the scholastic theories of politics, but will try to do this, naturally, only in broad outlines.

To begin with I'd like to say that I do not want to dwell on those 'freedoms' or 'liberties' which are mentioned in a huge mass of privileges which were given by medieval rulers to their subjects well into the modern times, in order to let the receiver participate in the decision making of the body politic of their time. These privileges were in those times so to speak instruments of political participation, but they were connected only loosely with that sort of freedom we are looking for. We, rather, are looking for the freedom which was sought as a fundamental requirement for life and as an universal claim, which cannot be thought of in relationship to special rights and 
privileges of certain social groups within the body politic, but must be the nucleus, the substance of individuals and their self-onsciousness in social life. Our question is : how did the medieval ('scholastic') theory of politics understand such claims of liberty for individuals and how did political treatises classify freedom in their designs?

I will turn first to Thomas Aquinas. Then I'll give a glance to Giles of Rome(Aegidius Romanus), in order to move on to Marsilius of Padua and William Ockham. I think that in this passage through some highlights of late medieval classicists of political theory the subjects of our considerations will be comprehensive enough to capture a variety of answers which are colored differently. It must be clear from the beginning, though, that I cannot go into an encyclopedic overview, but can only give a brief overview of some important authors, who are different enough to give us a balanced answer to our question.

Thomas Aquinas did not give freedom a central place in his political writings. Whereas he had without a doubt an astonishing architectural imagination, he actually did not grant freedom a place of its own in his theory of political rule. We should remember that Thomas Aquinas did not write a single comprehensive book on political theory as a whole. Rather, he communicated his thoughts in scattered remarks. Only once in his life did he write a treatise on the subject, entitled "On kingship dedicated to the King of Cyprus(De regno ad regem Cypri)". This was probably at the very end of his life (about 1276), shortly before that great crisis in his life, which caused 
him to stop writing a whole series of treatises. In this manner also his sole political treatise remained fragmentary, which was obviously not something he planned. Only after the death of Thomas, about thirty years after 1274, i.e. about the year 1305, Ptolemy of Lucca, a former student of Thomas Aquinas, wrote a consecutive part for the treatise, which found its way into the later medieval editions of the treatise and is until today often combined with Thomas' text.

Let us consider here only the first authentic part of the text, where discussions on specific constitutional questions are presented. Today you can still find specialists discussing the question of whether this (short) text was a random assemblage of different notes by Thomas put together by some ignorant person after his death. This idea was published by the American scholar Ignatius Theodore Eschmann several times and he has found some followers since, but I think this is totally wrong. I am convinced that this first part of "On Kingship(De regno)" is a genuine work by Thomas and has its own special worth because it expresses Thomas' genuine thoughts on politics.

Thomas started this "mirror for princes", writing a special treatise in that literary genre which was the main one for political treatises in the high and later Middle Ages, the "specula principum". He wanted to dedicate the text to the king of Cyprus as a helpful guide for the practical good life of a ruler. But because it remained unfinished, it probably never reached the royal court of Cyprus. Thomas himself wrote in the "proemium" of the 
text that he was willing to present to the royal addressee "a gift at once worthy of Your Royal Highness and befitting my profession and office".2) That was without any doubt Thomas' profession as a teacher at a university and his office as a theologian. He then begins to develop a theory of kingship and rulership, a very 'modern' one, fitting for his own time. He was one of the first scholastic thinkers to use the then brand new Latin translation of the Aristotelian 'Politica', which had reached Western Europe by only about 1265, at the most ten years before Thomas sat down for his own treatise. Thomas used this 'trendy' scientific method now again as the very first author in an unusual way, building with the terms of the Aristotelian 'Politica' a theory of his own. He did not write an explanatory commentary on the new and much awaited text. He applied Aristotelian patterns that were conceived by Aristotle (in ancient Athens during the fourth century before Christ) now for an analysis of his own time, fitting for Italy and Italian communities and principalities of the thirteenth century of the Christian Era. So his 'mirror of princes' is totally different from the earlier texts of this name, which were written in the earlier 13th century. He knew the most important ones of these texts certainly well, at least he knew the big compilation of excerpts and quotations, which were collected at the Friars Preachers' convent of Saint Jacques in Paris under the leadership of

2) Celsitudini dignum meeque professioni et officio congruum cited here after St. Thomas Aquinas: On Kingship to the King of Cyprus, done into English by Gerald B. Phelan, revised with introduction and notes by Ignatius Theodore Eschmann, O.P.(Toronto 1949), p. 2. 
brother Vincentius of Beauvais about 30 years before, in the forties and fifties of the century, and perhaps - but this is only a speculation - he had himself participated in accumulating them and heaping them together, when he had been a young Dominican student there. But certainly he had seen the huge compilation and knew it.

But Thomas wanted to do things differently. He did not want to bring that endless material of traditional authorities together into a somehow manageable handy package in a sort of 'Readers Digest' of all the important materials on the topic, as was done by Vincentius. Instead of this, Thomas wanted to provide a real theory of political power, on which an analytic and independent judgement on the rulers and their rulership of his own days could be based. Admittedly, only the basis of the whole project was laid in the first book. The final execution of books II to IV is lacking as well as the exemplary treatment of specific issues. Therefore, we do not know all the ideas Thomas wanted to tell his contemporaries.

Thomas stayed quite monosyllabic on the question of freedom as a basic requirement of any political organization: Here he looks to Aristotle very closely. Of course, it does not escape him that the ancient Greek philosopher had seen in freedom the basic requirement of political life in the ancient Greek city state, the polis, declaring e.g., that only free men can be participants of decisions on the weal and woe of the city state, while all others are excluded either for a short time (like children who had to wait to become adults) or are excluded 
from any participation (like the strangers and slaves and with Aristotle, too, the wives, who were not allowed to have any part in political decisions).

Thomas did not specifically cite all these notes, but he takes over the Aristotelian pattern, particularly in its fundamental considerations for the societal endowment of man as such, when he emphasizes that alone the social destiny of man - who is, according to Aristotle, an "animal sociale et politicum" (i.e. a societal and political animal) - cannot be understood properly if one does not understand that the "reasonable end" of the whole multitude of men must be reached by all. All men are reasonable. We understand therefore his argument: "A thing is rightly directed when it is led towards a befitting end. Now the end which befits a multitude of free men is different from that which befits a multitude of slaves, for the free man is one who exists for his own sake, while the slave as such exists for the sake of another." 3) The "finis conveniens" of a multitude of men or of a people can only be a reasonable one (this argument of Aristotle is taken over by Thomas). But, and here Thomas differs from Aristotle, when he declares that a multitude must be ordered by one man, and this is the king, towards the convenient end, because otherwise all would seek what's best for themselves, each for his own, and not the common good.

This is for Thomas Aquinas the fundamental reason for choosing the monarchy as the best form of government. The 3) On Kingship, S. 7 
difference between a monarchy and a tyranny is not to be sought in the freedom of the people, but in the relation of everyone, of the people and of the ruler, to the common good. From this definition Thomas deduces immediately what is a correct and rational ruler. Ruling has as its goal the bonum commune, the common good of all, not the bonum privatum of the ruler. "If therefore a multitude of free men is ordered by the ruler towards the common good of the multitude, that rulership will be right and just, as it is suitable for free men. If on the other hand, a rulership aims not at the common good of the multitude, but at the private good of the ruler, it will be unjust and perverted rulership." A quote from the Bible is for this statement a flank protection: "Woe to the shepherds that feed themselves seeking, that is, their own interest"(Ezech 34.2).

It is clear, Thomas does not actually establish freedom as a condition of good rulership. He is trying rather to establish justice as a precondition of a good ruler's function. Thomas declares that a rule will be iniustum et perversum, i.e. unjust and perverted, when free men are determined by others (and you can add to this the words: like slaves), while the "right and just" rulership is leading each free man to his own reasonable goal. It is clear: The universal call for freedom here is only the attempt to follow up an emphatic demand of justice, and that is linked narrowly with the Augustinian tradition, which was for the whole Middle Ages an almost self-evident demand. Closely related to this is also the juxtaposition that a 'right and just' rulership over free men is the contrary of an 'unfair and abusive' rule, which is qualified from the 
outset as a regimen iniustum: "Such a ruler is a tyrant ... because he suppresses (the people) by his power and does not govern with justice."

Here Thomas reinforced the Aristotelian statement, which had said that a ruler aiming at his own good was a 'despotes (despot)' a man who is ruling over slaves e.g. in his own household), whereas the medieval theologian Thomas Aquinas already saw this figure as a 'tyrant'. Thomas does not fail to deliver in the course of his treatise a longer discussion on prevention and relief from tyrants, an argument which should later on win a central role in the design of late medieval resistance theory. The explanation by Aristotle that the city state of the polis is and should be a community(koinonia) of free men is now sharpened and deepened into a quasi-metaphysical statement, that only a community of free men can be a 'right' political association, any other grouping is already with Aristotle subject not only to be a "constitutional degeneration', but also a 'perversion(parekbasis)' of monarchy. At the same time Thomas goes on and adds here the verdict that tyranny would be the worst perversion of the right and just' and therefore 'monarchy' would be the 'best' constitution.

Certainly, these are rather distinctions in accents, and they do not mark heavy differences in argumentation between Aristotle and Thomas. The two lines of argument can be converted easily into each other. But the stronger connection to the ideal of justice, which Thomas Aquinas has made, increases the glory of freedom and lets it shine brighter. We need not 
consider here the consequences, which follow from this discourse later on in the fragmentary remainder of Thomas' treatise On kingship : indeed, freedom plays there a lesser role than the tyrant problem. The justification(or rather non-justification) of a tyrannicide(the murder of tyrants) in the remaining fragment is not entirely clear. But this has not to be considered here in connection with Thomas' use of the concept of freedom in politics. Neither will we look at the demarcation of responsibilities of regnum and sacerdocium, of King and Pope in Thomas' theory.

The massive and indissoluble nexus of freedom and justice which we find in his conception had consequences. This nexus laid down by Thomas was further on a solid base for later political theories, especially for students of Thomas. For instance, let us look at a single example: Ptolemy of Lucca, a student of Thomas in Paris and for some years in Italy his confessor (sent to him by the Order of Friars Preachers) has drawn an unusual consequence from this Aristotelian fundament laid by his teacher, which was not common in the Middle Ages: he expressly preferred the constitution of a city state, i.e. a republican order of the state, to monarchy, which was chosen generally by medieval theorists as the 'best order'. This was not too frequently done in the Middle Ages.

But Thomas' connection between justice and freedom was not an automatism. That is proven by a famous text, which was written a generation later by Aegidius Romanus, Giles of Rome. The book with the title De regimnine principum was later on in 
the Middle ages incredibly successful. We may say that this book was the real 'bestseller' of all the medieval political treatises. Nowadays there are left to us in different European and North American libraries nearly 300 manuscripts of this text, in different languages, in Latin and in several vernacular translations: French, Castilian, English, German, even Hebrew, and some others.4) Giles of Rome perhaps had heard lectures by Thomas Aquinas at the university of Paris, although he almost certainly was not actually one of his closer students - as he was the member of another religious order, the Augustinian Hermits, whereas Thomas belonged to the Friar Preachers. In his treatise Giles recommends to the 'right' prince an earnest commitment to justice. The treatise uses several chapters to explain this demand for justice as the central virtue of the ruler, and Giles repeatedly emphasizes that here is the dividing line separating kings from hideous tyrants. Tyranny is described at length in all its awfulness and insecurity, whereas the liberty of the subjects from suppression is not discussed in these chapters which have to tell, indeed, something on the virtues of the ruler. Only very late, as a (sixth) group of meritorious subjects, there are mentioned men who persecute a tyrant, because they try to free their homeland from a tyrant's oppressions. But this

4) A first overview is given by Wilhelm Berges, Die Fürstenspiegel des hohen und späten Mittelalters (Leipzig 1938 [Reprint: Stuttgart 1952]); now look especially for the French translations to Noëlle-Laetizia Perret, Les traductions françaises du De regimine principum de Gilles de Rome, Parcours matériel, culturel et intellectuel d'un discours sur l'éducation (Leiden-Boston 2011). 
is not written in order to give them a special consideration. Generally, the question of what should be called kingship and what tyranny was answered by naming the two criteria we know already from Thomas Aquinas: subjectively by the virtue of the ruler and objectively by answering the question of whether he was serving the common good, or the private good of the ruler. The liberty of the subjects might have been implicitly involved there or even must have been understood as contained in the virtue of the ruler, but as far as I can see, this is nowhere explicitly written in Giles book.

Later on in his life, when Giles of Rome wrote his book On the ecclesiastical power (De potestate ecclesiastica) at the court of pope Boniface VIII about the year 1302, Giles did not waste any remark on the freedom of the members of the church under the pope whom he saw at its highest hierarchical top. Where he was describing the relationship between the pope and temporal rulers, Giles said nothing about the freedom of European kings or peoples from the demands of the pope (their spiritual leader), that means in describing the relationship, which in modern times we would call the relations of church and state, he was content to say not a single word on freedom. The Latin word liber(free) only appears when Giles is ascribing to the pope a libera potestas(i.e. a free competence), whereby he could claim that in the last resort always all decisions belong to the pope, although they were normally assigned to 'lesser' authorities. This is exactly the argument Giles is producing here - just as God himself is able to let everything in the world go its natural course and let all creatures do their 
normal work regularly, he is also able in some cases casually to suspend this normal procedure and perform a miracle, which is the breaking down of normal relations and effects. By such miraculous effects God shows only his own abilities. He is always the Lord and this is made clear by these exceptions of the "normal" course of things. In the same manner the pope is free in making the last decisions. By doing so he is showing only his own abilities. There is no word on the freedom of the subjects in this argumentation. The theory of Giles of Rome shows clearly that the call for freedom, which was still so present in Thomas Aquinas, was gone and in its place was a clear and unquestionable assignment of competences to the ruler, who could hold alone for himself the right of making decisions in this system.

Later on we meet, however, new reflections, which are in a certain sense a fresh and new result of Aristotelian theories in medieval circumstances. I want to show this by approaching Marsilius of Padua. For Aristotle there was a clear difference between free men and slaves. The Greek philosopher could speak even of 'slaves by nature'(douloi physei in Greek, or servi natura in Latin), which meant that there are men who were condemned by their natural endowment to a servile status, because they could not rule themselves. I do not want here to go to the development of commentaries in scholastic Aristotelianism regarding this special point in detail,5) but it is

5) See especially Christoph Flüeler, Rezeption und Interpretation der aristotelischen "Politica" im späten Mittelalter(Bochumer Studien zur Philosophie, 19/1-2XAmsterdam/ Philadelphia, PA 1992)[=Phil. Diss. (Freiburg/Schweiz 1989)]. 
clear that a Christian thinker could not fail to overlook the fact that all human beings are redeemed by Christ and therefore had a common basic human condition. This gave to the theory of slaves and free men a new shift towards an equality of rights for all men within a community.

We can see this clearly with the Paduan philosopher and physician Marsilius of Padua and his famously weighty book Defensor pacis, finished in Paris at the university in summer 1324, about one generation after Giles had written his texts. Certainly, this "Defender of peace", according already to his title, is not a hymn of freedom, but a 'defense of peace' within the political community. Marsilius is trying hard to reach this aim by rejecting the unjustified claims of the Roman bishop and pope to make all decisions, not only in spiritual affairs, but also in normal political ones. This is not done primarily through the evocation of freedom from ecclesiastical patronage, but through an ingenious political philosophy of Aristotelian design of political decision-making. Marsilus is looking at the legislation, because for him the main instrument of order in a community is the enactment of a regulation of life by a law which is enforced by a coercive command by the lawgiving legislator. The only legislator possible must be the one who is able to make such laws and give an coercive command to all. This one is according to Marsilius alone the community of all citizens (or its weightier - or prevailing - part). This is the nucleus of his whole theory. But where do we find freedom in this lawgiving complex? The word libertas civium is used, if we believe the 
word index of the modern editions of the book, in just two spots in more than 500 pages of Latin text: In Dictio I , cap. 12, when he is proving the sole responsibility of all the citizens together for the legislation, Marsilius is referring to freedom, using the same quotation from Aristotle's Politics, to which also Thomas Aquinas had relied (but here Marsilius is going much further into the modern direction than Thomas Aquinas). I quote:

"for because 'the city is a community of free men', as we read in Politics III chapter 4, any and every citizen should be free and not suffer the despotism (i.e. the servile dominion) of another. But this would not be the case if someone or few of the citizens passed law upon the universal body of the citizens on their own authority, for in legislating in this way they would be despots over the others. And therefore the rest of the citizens (viz. the more extensive part) would either take this law badly - however good it was - or not accept it at all: as all the victims of contempt, they would protest against it, and since they had not been involved in its passage they would not observe it at all."6)

I need not emphasize that here the basic Aristotelian text shines through the lines immediately, and is indeed explicitly cited. The problem here seems to me to ensure compliance with the legislation, the expectancy that the regulations shall be followed up by all. This is here the reason for the argument that freedom is the presupposition of the political action of 'legislation'. It remains significant that Marsilius did not put

6) Marsilius of Padua. Defensor pacis. I.12.6. Cited from The Defender of the Peace. Ed. and Trans. Annabel Brett. Cambridge. p. 70. 
here (like Thomas) solely 'tyranny' in the place of Aristotelian 'despotism', in order to justify the fight against tyranny. By these arguments Marsilius is justifying his statement time and again that in all constitutions the actual and rightful legislator is always 'solely(tantummodo)' the community of citizens who participate as voters in state affairs. Only this thesis allows Marsilius to make rigid conclusions against the interference of the Church and pope into the political affairs of the emperor, of the kingdoms of Western Europe and of other principalities and cities. This was not found in Aristotle, but is genuine Marsilian theory, and I add it was the core of his theory. Marsilius had found this argumentation beyond the texts of Aristotle, but not without an Aristotelian argument backing it up, although Aristotle's intention had been quite different.

At the same place Marsilius used freedom to support a central point of his theory.

"For the greater part of the entire common human sufficiency rests in their being rightly established, whereas under iniquitous laws there is only intolerable slavery, oppression and misery for the citizens, which ultimately results in the dissolution of the polity."7)

Oppression, servitude and misery apparently derive from the adoption of bad laws. But especially in order to avoid such sinister effects the political community had been erected. The core of polity is safeguarded by rightly established laws. This is

7) Ibid. I.12.7. Brett p.71. 
the Marsilian message to his time. If legislation is done in the right way, and that means by all free men of the polity, then the polity is fortified and even guaranteed. Marsilius is looking at the variety of the 'modes' of possible constitutions described by Aristotle (the monarchy, aristocracy and democracy and their flawed transgressions of 'tyranny, oligocracy, ochlocracy'). His result is important for the purposes of locating freedom in his context:

"All pricipate is either over willing or unwilling subjects. These are the two generic kinds of principate, i.e. tempered <i.e. monarchy> and flawed <i.e. tyranny>. '. Each of the said modes shares more in the truly royal the more it is over willing subjects and in accordance with a law passed for the common advantage of these subjects. It savours of tyranny, by contrast, the more it departs from these conditions, viz. the consent of those subject and a law established to the common advantage." 8 )

For Marsilius, in an unfree system, the core area of the political constitution is perverted, the dissolution of the Aristotelian politia therefore may follow, or better: must follow. There comes to mind the preaching of 'Freedom and Democracy' in the second half of the 20th century which should also foster the prosperity of entire societies. Marsilius is seeing the reason for this connection between freedom and prosperity in the fact that the laws enacted in the right manner by all can only be effective if and because they have derived 8) Ibid. I.9.7. Brett, p. 47. 
their potentia coactiva(coercive power) from the potestas coactiva(the coercive competence) of the legislator. That is, they derive their binding force from the binding force of the compelling legislator.

But if the legislature is - at least ideally - coincident with all the citizens, this compelling power is a compelling or coercive force(potestas coactiva), which is exercised by all of the citizens together. Therefore, their force is directed mainly and merely against themselves. We remember the free man as causa sui with Thomas of Aquinas! When 'the' legislator is forcing himself, it is not discussed whether there is need of a majority, or even a qualified majority or unanimity of the whole? What happens to the dissenters? Such questions are not asked, let alone be answered in the book, but this form of majoritarian tyranny over dissenters is also exerted by the 'volonté generale' of Jean Jacques Rousseau three centuries later. In principle, in his argumentation, Marsilius is fostering freedom as a prerequisite of good government with ideas found outside of the Aristotelian context.

Here, we note first the necessary consent of the governed, as legislators together with the quasi-objective common good, which benefits everyone. This becomes in the Defensor pacis the decisive criterion on a sliding scale of possible exacerbation, which determines the location of a specific constitution: The more consensus there is, the 'better' is the Constitution, and vice versa in the worst case. In his short summary at the end of the treatise, Marsilius underscores once again the importance of freedom: he 
says:

"This treatise will be called The Defender of Peace, because it discusses and explains the particular causes by which civil peace or tranquility is preserved and exists, and also those through which its opposite, strife, arises, is prevented and is removed. For by its authority [i.e. the authority of the book] cause and harmony of divine and human laws and of coercive principate of any kind $[\cdots]$ can be known. Furthermore, both prince and subject, $[\cdots]$ can understand by this treatise what they must do in order to preserve the peace and their own liberty."9)

Freedom is gaining here almost the same importance as peace and tranquility. Liberty and freedom in a definitely Aristotelian cloth are set beside peace, which Marsilius was willing to defend against papal aggression.

Freedom was set in a similar position in the political theory of a contemporary writer of Marsilius, who still today is considered like him a "classic" medieval theorist of politics. The English theologian William Ockham demanded freedom in politics rather more comprehensively than the Padovan thinker. It is certainly much more difficult to explain in a few words Ockham's ideas of freedom than to visit the few places where Marsilius is speaking of liberty. Ockham's writings are full with the pathos of freedom, and this is already the case in his 'academic' texts which he had written during his university career in Oxford. His theology seems centered in a deep

9) Ibid. III.3. Brett, p.557. 
experience of God's free power, 10) Other topics of his theology are guiding us into the same direction: for instance, his doctrine of grace was sometimes argued in research to be Pelagian or at least semi-Pelagian, that means Ockham was accused of overemphasizing heavily the natural possibilities of men to live on Earth without sin. But Ockham stressed the point that God himself wanted his creatures to be free and in liberty. We do not have to go into details here, but that is certainly in connection to Ockham's idea that also the creature must be able to use its free abilities in freedom against the creator. His political theories originated not from an Aristotelian program, but in his apology of the Franciscan way of living. Ockham wanted to explain against papal decrees that Franciscan brethren had the freedom to a voluntary renunciation of property and could renounce totally and in free decision all property on Earth and could become mendicant by sustaining their life without the order of a pope or another man in order to follow the example of Christ and his disciples and live like the founder of the Franciscan Order, Saint Francis, or the apostles. ${ }^{11}$

From this starting point Ockham developed a complicated theory

10) Cf. J. Miethke, Ockhams Weg zur Sozialphilosophie (Berlin 1969).

11) J. Miethke, "Der theoretische Armutstreit im 14. Jahrhundert, Papst und Franziskanerorden im Konflikt um die Armut", Gelobte Armut, Armutskonzepte der franziskanischen Ordensfamilie zwischen Ideal und Wirklichkeit vom Mittelalter bis in die Gegenwart, eds. Hans Dieter Heimann, Angelika Hilsebein, Bernd Schmies, Christoph Stiegemann (Paderborn 2012), pp. 243-283. 
of political structures, which he explained in voluminous writings. All of them are interested in the legal framework of reasonable political behavior in his contemporary world by maintaining free choice and the voluntary behaviour of men. We cannot give an account here of Ockham's theories in greater detail, but we are able to point to his use of freedom and his specific call for free men and Christians. The pathos of freedom is already evident in his casual remark that the Emperor (and therefore, in Ockham's understanding, the monarchic ruler of the world) can only be addressed usefully as the ruler of free people, if one respected his dignity and the dignity of mankind. The 'dignity of the human race' demands that the subjects of the emperor are not treated by the emperor as mere slaves, "and therefore this dignity of the human race would fall aside, if the Emperor was allowed to treat free men in all things like slaves". This Aristotelian argument still sounds very courageous today if we remember the situation in which it was spoken: It was formulated in a treatise written at the emperor's court in Munich during the last years of Ockham's life.12) The English protége of the German emperor is daring to remind the ruler that he is ruling over free men who are not his slaves. That seems to me remarkable, as it does not fit totally to contemporary attempts to use Roman legal ideas of late antiquity in describing the competence of an medieval emperor.

12) III.2 Dialogus II.20 (fol. 255vb): Dignitati enim humani generis derogaret si omnes essent servi imperatoris et ideo derogaretur eidem si imperator in omnibus posset tractare liberos sicut servos. 
But be that as it may, in his main political work, the huge fragmentary 'Dialogus', Ockham wanted, as he declared in the proemium, to give a summa, a summary of the disputes of his time between pope and rulers, or a comprehensive textbook (however a new kind of a textbook). Here Ockham explains the central claims of the papal court. He had read numerous treatises of other authors, as he himself has said there, and certainly, too, he knew the Defensor pacis of Marsilius, but he wrote a new and fresh overview of possible actions in political affairs, discussing arguments for and against political claims of both sides of the conflict. He denies again and again the assertion that the church, including the pope, had received from Christ and God the 'fullness of power (plenitudo potestatis)' in spiritual and political affairs. And within these discussions he presents again a special argument: $A$ citation from the letter of the Apostles James and Paul, who asked the Christians to understand the Christian religion as a lex libertatis (a law of freedom), and more than that, as a lex perfectae libertatis (a law of perfect freedom). Ockham cites these words from the Bible to prove the absolute inadequacy of the papal claim to the "fullness of the official competence.' And Ockham does not forget to make an in-depth investigation about what really was meant by such 'Christian freedom.' This is for him a sort of shield against any demand for unconditional obedience to pope, clergy and church.

"The evangelical law is a law of liberty, by which Christians are torn out of the bondage of the ancient law of Moses in order not to be drawn again into bondage." If the Pope had the 
right to command every Christian by virtue of his plenitudo potestatis, which is not contrary to divine law or the law of nature, then the Christians were not really free in relation to the bondage to the law of the Old Testament. Ockham says expressly: "Then Christian law would be by virtue of this appointment by Christ a law intolerable bondage or slavery." The new covenant of the New Testament must have been given as a law in which there is allocated a tangible, real progress of liberty in relation to the Old Covenant, the Old Testament. Ockham is proving in an elaborate manner that this extra freedom, this greater freedom, cannot be interpreted away by exegetic excuses. He supports this statement with an unusually large number of Bible citations and patristic quotations in order to save this 'literal' understanding of the words of the apostles from any comparative volatilization: here was not meant freedom from the bands of sin nor only freedom in the spiritual sense. If Christians should be subject in worldly affairs to the pope's decisions, an intolerable slavery would follow by necessity, and the Apostolic freedom would be left empty. In addition, within Christianity, there would inevitably arise "division and discord, wars, feuds, the whole Christianity will get in great danger and distress."13)

I have presented here Ockham's argument in some detail (but I could have presented it in even more detail!). I did this

13) III.1 Dialogus I.5: $\cdots$ si papa uteretur tali potestate privando reges et alios Christianos regnis et rebus suis pro sue voluntatis arbitrio et eos subiciendo servituti vel operibus servilibus, orirentur scismata et dissensiones, bella ac guerre inter Christianos, eciam periculum et dispendium tocius Christia nitatis. 
deliberately, in order to show how Ockham understood the promise of freedom as a real liberation from ancient bonds. In fact, according to his interpretation, the Christians should not only get spiritual release as in freedom from the servitude of sin; they should enjoy freedom in relation to the ancient state of the Old Testament, which they should be able to use in self- determined behaviour, independent of the authority of the Church hierarchy, of the clergy and the Pope. Applying this demand immediately to the relationship between pope and emperor or pope and Christian kings, Ockham wrote his Dialogus during the last big struggle between these representatives of state and church in the Middle Ages, but he analysizes for this endeavor the whole of Christendom in its secular political constitution.

But there is more. One question remains unresolved. If we identify the Christian law (lex evangelica) according to this reading of the Bible as the 'law of perfect freedom' in the realistic sense Ockham explained, there remains the question: Is it still possible under these conditions to tolerate the restrictions of freedom in more limited social relationships? What shall a Christian do with his serfs and slaves? Ockham's answer is cautious and not revolutionary at all. He insists on a literal understanding of the comparative in the apostle's expressions: The Bible is talking of a 'larger' freedom than was possible under the law of Moses. Therefore, besides their freedom in Christ, Christians are allowed to have slaves, even if no Christian can become a slave of any other man directly by the law of Christ. ${ }^{14)}$

14) III.1 Dialogus I.7: $\cdots$ lex Christiana non dicitur lex libertatis quia liberat 
The concept of perfection, as Ockham has written, is an absolute maximum, which retains a character of absolute appeal. In his answer to the question, the Franciscan theologian uses this theoretical argument from contemporary physics, connecting it to a traditional argument of piety. The Christian religion can

"rightly be called a law of perfect liberty, especially in relation to the Mosaic law, which had subjugated the believers to many sacraments and barely tolerable regulations of ceremonial law. Nevertheless, Christian law is not (in any sense) a law of most perfect freedom, because always there are degrees of perfection. Therefore, Christian law is not to be regarded to be absolutely the most perfect of all laws. In this mortal life never there will be an absolutely perfect freedom."15)

We should not overstress here the almost emphatic resignation in which Ockham explains that no ideal is feasible in this earthly life. We also do not need to trace here in detail the new physical theories of natural philosophy which were developed at Oxford University in the early 14th century, the

Christianos ab omni servitute, sed quia non premit Christianos tanta servitute quanta pressi fuere Iudei; et ideo licet regibus et aliis Christianis servos habere, licet per legem Christianam nullus Christianus fiat servus cuiuscumque.

15) III.1 Dialogus I.7: Merito debet dici lex perfecte libertatis, presertim respectu legis Mosaice, que quampluribus sacramentis et ceremoniis vix portabilibus subiectos involvit. Non [165] tamen dicitur lex perfectissime libertatis. In perfeccione enim sunt gradus, quia non omne perfectum est perfectissimum reputandum. Perfectissima autem libertas in hac vita mortali nequaquam habebitur. 
time when Ockham studied there, and which he might have remembered now in Munich when he wrote down the last part of the Dialogus. Oxford physicists had sought to conceptualize a new understanding of dynamics by calculation of different levels of intensity and thus they prepared the new dynamics of early modern science. This part of the history of scientific research of natural phenomena is not to followed up here. But Ockham here was content putting off absolute expectations until the coming of the kingdom of God, while preserving his hope for an absolute freedom without any reduction for a future to come. The tension between the 'already there' of perfect liberty and the 'not yet' of a most perfect freedom remains with him, I think, as a genuine Christian eschatological tension. We should not consider that as a pious modesty, but we should sense here the desire for freedom which is contained in the theory, as the dawn of modern and more democratic ideas in political thinking.

We have visited in a very restricted tour some positions of scholastic political theory, regarding problems of self-determined freedom. This is still today a necessary prerequisite for any democratic constitution of the modern state. In the middle ages this was far away from any chance of practical realization. It was not even thinkable in a consistent manner in the early middle ages. In late medieval times, the reception of Aristotle's political theory could be, as we have seen, the point of departure for several expeditions into this until then mainly unexplored terrain. We therefore have found 
ideas of universal freedom of men in our examination of political theorists. We met those ideas in no less than three major designs of political theory with authors who are considered to be so to speak classics of medieval political thought: Thomas Aquinas, Marsilius of Padua, and William Ockham. We also have caught some of the differences that distinguish their individual positions. Medieval political thought did not form a single unity of ideas, but existed as a discourse which is worthwhile decoding. In so far we have reached, as I think and as I hope to have been able to explain, a good deal of the prehistory of modern democratic freedom within medieval thought.

(Juergen.Miethke@zegk.uni-heidelberg.de/ Heidelberg University) 


\section{〈Reference〉}

\section{Primary sources}

Aegidius Romanus, De regimine principum libri III. Frankfurt am Main, 1968.

Ockham, William, Texte zur politischen Theorie Wilhelm von Ockham, Jürgen Miethke, ed., Stuttgart, 1995.

Marsilius of Padua, The Defender of the Peace, Annabel Brett, ed. \& tra., Cambridge, 2006.

Thomas Aquinas, On Kingship to the King of Cyprus. Trans. into English by Gerald B. Phelan, revised with introduction and notes by Ignatius Theodore Eschmann, O.P. Toronto, 1949.

\section{Secondary sources}

Berges, Wilhelm, Die Fürstenspiegel des hohen und späten Mittelalters, Leipzig, 1938.

Berges, Wilhelm, "Selbstbestimmung in der Geschichte." Freiheit als Problem der Wissenschaft(Freie Universität Berlin, Abendvorträge im Winter 1961/62), Berlin, 1963, pp. 147-160.

Brunner, Otto, Conze, Werner and Koselleck, Reinhart eds., Geschichtliche Grundbegriffe, Historisches Lexikon zur politisch-sozialen Sprache in Deutschland. Vol. 2. Stuttgart, 1975.

Flüeler, Christoph, Rezeption und Interpretation der aristotelischen "Politica" im späten Mittelalter, Amsterdam/ Philadelphia, PA, 1992.

Fried, Johannes, "Über den Universalismus der Freiheit im Mittelalter", 
Historische Zeitschrift 240, 1985. pp. 313-361.

Fried, Johannes, Die abendländische Freiheit vom 10. zum 14. Jahrhundert, Der Wirkungszusammenhang von Idee und Wirklichkeit im europäischen Vergleich. Sigmaringen, 1991.

Grundmann, Herbert, "Freiheit als religiöses, politisches und persönliches Postulat im Mittelalter", Historische Zeitschrift 183, 1957, pp. 23-53.

Lexikon des Mittelalters, vol. 4. München/ Zürich, 1989.

Miethke, Jürgen, Ockhams Weg zur Sozialphilosophie. Berlin, 1969.

Miethke, Jürgen, "Der theoretische Armutstreit im 14. Jahrhundert, Papst und Franziskanerorden im Konflikt um die Armut", Gelobte Armut, Armutskonzepte der franziskanischen Ordensfamilie zwischen Ideal und Wirklichkeit vom Mittelalter bis in die Gegenwart, Hans Dieter Heimann, Angelika Hilsebein, Bernd Schmies, Christoph Stiegemann, eds., Paderborn, 2012, pp. 243-283.

Perret, Noëlle-Laetizia, Les traductions françaises du De regimine principum de Gilles de Rome, Parcours matériel, culturel et intellectuel d'un discours sur l'éducation. Leiden-Boston, 2011.

Ritter, Joachim ed., Historisches Wörterbuch der Philosophie. vol. 2. Basel, 1972. 